ROCZNIKI HUMANISTYCZNE

Volume 67, issue $2-2019$

SELECTED PAPERS IN ENGLISH

DOI: http://dx.doi.org/10.18290/rh.2019.68.2-3en

EWA M. ZIÓŁEK

\title{
ON A VIRTUOUS OFFICIAL AND A GOOD CITIZEN: \\ CANON AUGUSTYN LIPIŃSKI'S PHILOSOPHY \\ OF EXERCISING POWER \\ (BASED ON THE SERMON PREACHED IN KRAKOW \\ ON $8^{\text {th }}$ MAY 1810)
}

The French-Austrian war going on in 1809 also played a significant role in the history of the Duchy of Warsaw. The Polish troops commanded by Prince Józef Poniatowski captured all the lands of the Third Austrian Partition of Poland, the so-called Western Galicia, and a considerable part of the First Partition lands. Ultimately, not all of this conquest was included in the Duchy. On the strength of the Treaty of Schönbrunn between Napoleon and Francis I, that was signed on 15 October 1809, Western Galicia and the Chełm Region were included in the Duchy, and it was only a rather small part of the first partition. Finally, at the end of 1809 Frederick Augustus I, the Warsaw Prince, officially assumed power over the new part of the country.

In spring of the following year, 1810, the monarch, along with his wife Queen Amalia and his daughter, Princess Maria Augusta, made a tour of the new departments. On $7^{\text {th }}$ May he came to Krakow, enthusiastically welcomed as the successor of the Polish kings. It should be remembered that for Polish society Frederick Augustus was not a ruler by Napoleon's grace, but one elected by the parliamentary estates, as was provided for by the Constitution of $3^{\text {rd }}$ May 1791. Hence, it should not be surprising that he was received in Krakow in accordance with the entire ceremony due a king, which was described in detail by the press of that time. ${ }^{1}$

Dr hab. EwA M. ZIÓŁEK - John Paul II Catholic University of Lublin, Institute of History, Department of Modern History; address for correspondence: Al. Racławickie 14, 20-950 Lublin; e-mail: ewa.ziolek@kul.lublin.pl.

The Polish version of the article was published in Roczniki Humanistyczne 61 (2013), issue 2.

${ }^{1}$ Gazeta Krakowska [further: GK] 1810, No. 37-43. The descriptions were published in con- 
On the next day after the arrival of the royal couple the feast of St Stanislaus of Szczepanów fell. The royal family attended the solemn pontifical mass celebrated in Krakow Cathedral by Bishop Andrzej Gawroński. Just before the ceremony the Bishop welcomed the monarch and paid homage to him on behalf of the diocesan clergy. Representatives of the highest authorities also participated in the ceremony - Prince Józef and the Prefect of the Krakow Department, Henryk Lubomirski, together with representatives of all departmental and municipal offices. ${ }^{2}$ Considering the rank of this assembly one of the outstanding preachers of those times, the Custodian of the Krakow Chapter Fr. Augustyn Lipiński was chosen to deliver the sermon. $\mathrm{He}$ was considered to be a man of broad intellectual horizons and a great patriot who understood his patriotism fully - not only as heroism in extreme situations, but also as honest and painstaking work for the good of the country that has to be done every day. It is worth adding that Frederick Augustus appreciated his preacher's achievements and awarded him the Order of St Stanislaus. He was also going to nominate him to be the Bishop of Poznań. However, this appointment did not take effect due to Lipiński's death in $1814 .^{3}$

Thus, on the feast of St Stanislaus, at the tomb of the saint, Canon Augustyn Lipiński delivered a sermon in the presence of the King and numerous high state dignitaries. This was a rather special sermon - despite its title we can look in vain for a broad history of the Saint's death or for a reference to a lesson that can be drawn from it. ${ }^{4} \mathrm{He}$ was mentioned only twice - as the patron of the day and as the patron of Poland. ${ }^{5}$ It should be assumed that for

secutive issues since the editors tried to present the event in as great detail as possible, so the accounts had to be divided into a number of parts. See also: Izabela KLESzCzowA, Ceremonie i parady w porozbiorowym Krakowie 1796-1815 [Ceremonies and Parades in the Post-Partition Krakow 1796-1815] (Kraków: Wydawnictwo Uniwersytetu Jagiellońskiego, 1999), 52-65.

${ }^{2}$ GK 1810, Nr 39; KleszCZOwa, Ceremonie i parady, 55-57.

${ }^{3}$ Ludwik ŁĘTOWSKI, Katalog biskupów, prałatów i kanoników krakowskich [A Catalogue of Krakow Bishops, Prelates and Canons], vol. III (Kraków: W drukarni Uniwersytetu Jagiellońskiego, 1852), 253-254; Wojciech Bartel, "Lipiński Augustyn Karol Boromeusz," in Polski Stownik Biograficzny [Polish Biographical Dictionary], vol. XVII (Wroclaw, Warszawa, Kraków: Ossolineum, 1972), 387-388; Zbigniew BARAN, "Kraków kościelny w czasach Księstwa Warszawskiego [Ecclesiastical Krakow in the Times of the Duchy of Warsaw], in Kraków w czasach Księstwa Warszawskiego [Krakow In the Times of the Duchy of Warsaw] (Kraków: Towarzystwo Miłośników Historii i Zabytków Krakowa, 1989), 99, 102-103.

${ }^{4}$ Kazanie $w$ dzień S. Stanisława biskupa i męczennika w przytomności najjaśniejszego Fryderyka Augusta króla saskiego, xiażęcia warszawskiego miane przez x. Augustyna Lipińskiego kustosza katedralnego krakowskiego dnia 8 maja 1810 [The Sermon Delivered by Rev. Augustyn Lipiński, the Krakow Cathedral Custodian In the Presence of His Majesty Frederick Augustus King of Saxony, Duke of Warsaw on 8 May 1810].

${ }^{5}$ Ibid., 11-12, 50. The first mention, in fact, concerns the saint's tomb and his relics beside 
the preacher the feast was only a pretext for expressing - in the presence of the monarch and his ministers - his opinion about what it means to be a good citizen and a virtuous representative of the authorities. It is characteristic that he addressed the listeners with the word "Gentlemen" many times, clearly directing his words to the King's officials who were listening to him. ${ }^{6}$

The fundamental assumption that was beyond a shadow of a doubt for the preacher was the conviction that the monarch's power - and only his comes from God, whereas the Roman Catholic religion was the foundation of the country. ${ }^{7}$ After the invocation in which he greeted Frederick Augustus as the legitimate King, the successor of the kings of Poland, he stressed that with the Monarch's visit Krakow was celebrating the renaissance of the Polish nation. Its former fall was the result of the fall of faith. The author substantiated his thesis by supporting his argument with properly chosen quotations from the Old Testament, Pauline epistles, and writings by the Fathers of the Church. He remarked that the Republic of Poland had been a power when faith had flourished in it. The power broke down "when at last came, and in our days multiplied, the sons of disbelief who give themselves the name of philosophers." ${ }^{\prime 8}$ Hence, the fall of the Republic of Poland was the result of the far-reaching influence on Polish society of a pseudophilosophy, or rather the ideology whose consequence was the French Revolution ${ }^{9}$. The Revolution was not mentioned straight-forwardly, only its de-

which the ceremony was taking place, and it is supplemented by the author's extensive footnote (it should be doubted if the footnote was read during the ceremony; it is rather designed for the readers of the sermon - ibid., 11-16). It was wholly devoted to the great veneration that Queen Maria Josepha, the wife of Augustus III, and so the grandmother of Frederick Augustus, held the saint in. In her testament she donated a golden rose to the saint's tomb that she had been given by Pope Clement XII and a silver painting to Saint Mary's Basilica. The gifts were sent by Frederick Augustus in 1801 .

${ }^{6}$ In any case, when he addressed the monarch he always said "Your Majesty", so these phrases clearly directed particular fragments of the sermon to the proper part of the audience.

${ }^{7}$ This view has its source in the pre-partition tradition. The Catholic Church had then the position of the dominant religion, but also a lot of independence from the state authorities while at the same time participating in the political life of the country. This formed a peculiar alliance between the throne and the altar, not found in any other country and ensuring peace inside the country, see: Ludomir BIEŃKOwSKI, "Oświecenie i katastrofa rozbiorów (2. poł. XVIII w.) [Enlightenment and the Catastrophy of the Partitions (the Second Half of the $18^{\text {th }}$ Century)], in Chrześcijaństwo $w$ Polsce. Zarys przemian 966-1979 [Christianity in Poland. An Outline of Transformations 966-1979], ed. Jerzy Kłoczowski (Lublin: Towarzystwo naukowe KUL 1992), 361.

${ }^{8}$ Kazanie $w$ dzień S. Stanistawa (The Sermon on the Day of St Stanislaus), 15-16.

${ }^{9}$ In no fragment of the sermon does Lipiński admit that the propagators of the contemporary views that he identifies with revolutionary ideology are philosophers. He always calls them "socalled philosophers", "ones who call themselves philosophers" etc. 
scription was given as a criminal event destroying all social order and building a new one "on the ruins of the Altar and the throne." ${ }^{10}$ For the preacher, a close connection between the altar and the throne - in this sequence - was a guarantee of the proper order in the country. Breaking this connection, however, only resulted in the fall of the country, since the Church, he believed, was eternal and indestructible. Hence, the activity of contemporary pseudo-philosophers, above all, had harmed the country, authority and society, as the main principle they propagated was the conviction that the happiness of nations did not depend on belief in God, but on virtuous officials and good citizens.

However, can an official be virtuous and a citizen be good without religion? The preacher's whole argument aimed to show that this is impossible, and that modern ideologists' reasoning is erroneous. He states that the government's will alone can inspire neither clerks nor citizens to virtue. Only the tenets of religion form the fundamental principles indicating to human reason the duties of virtuous work, as well as the duty to be a good citizen to the whole of society, and they also enable one to observe such tenets. ${ }^{11}$

In order to be able to show this relationship Lipiński first presented a catalogue of the official's and the citizen's virtues. They were: impeccable faith, unblemished reliability, fearless valiance in dispensing justice to everyone irrespective of his social position, tireless work and the constantly acquisition of the abilities necessary for carrying out one's duties well. An official has to do it all because of his will to serve the country, and by no means to satisfy his own ambitions or desire to be promoted. He has to agree to the monarch's will as this will is guided by Providence, and under no circumstances may he show contempt for those subordinate to him, or deceive his co-citizens who are dependent on him. An official guided by justice in his work will be open to the voice of the oppressed, and he will not discriminate against the importance of issues depending on the social position of the petitioner. ${ }^{12}$

In turn, the virtues of a good citizen are basically reduced to broadly understood honesty, both in judging oneself and in judging others. This is why good citizens faithfully keep on doing their work, carry out their citizen's duties, do not succumb to indolence and idleness, but they also do not look to their own profit in this field to the detriment of other citizens. A good citizen prefers the

\footnotetext{
${ }^{10}$ Kazanie, 17.

${ }^{11}$ Ibid., $18-19$.

${ }^{12}$ Ibid., 20-22.
} 
good of his country to his own good, and in the end he cannot "stint on his wealth, health or his very life" when his Homeland is in need. ${ }^{13}$

The preacher also remarked that a catalogue of citizens' and officials' virtues formed in this way had been presented even by ancient, that is, pagan, philosophers. What does his polemics with contemporary thinkers consist of, then? First of all, of the conviction that basing these virtues on reason only, and not on religion, is perishable. He referred here to the contemporary experience, showing that separating these principles from religion and being rooted in reason might only result in the appearance of theories contrary to the rights of citizens and of the whole of society. In this way, from the godless contemporary philosophy the orator derived principles that some citizens adhered to, and which were fatal for the whole community: the pursuit of one's personal profit and comfort. He charged the contemporary elite with thinking that good and evil, virtue and misdeed, depended on one's place in the social hierarchy. Those who took higher positions usurped more rights, they might, in a way, decide what was right and what was wrong according to their own comfort, and they thought that "love of the public good should be shown only when there is hope of finding one's personal good in the public good." ${ }^{\prime 4}$ By reviling attitudes of this kind, Lipiński asked what might remain in such a country where citizens and officials would adhere to such ideas? He drew the listeners' attention to the fact that such views, although they had not originated in Poland, had reached our country - and ever more often cases of contempt towards the principles of religion could be seen, and at the same time greed and overweening ambitions were becoming ever more frequently the mainspring of people's actions. They resulted in the detriment of other citizens who were not treated as brothers but as competitors or, indeed, enemies who should be excluded by all means from the rivalry for influences and wealth.

On the other hand, observing the principles arising from the tenets propagated by the Christian religion caused social relationships to be built on the foundation of brotherhood between people. Social hierarchy and order arise from it - God established the rights and duties for the good of the people. This was followed by the necessity of giving everyone what he deserved, and also by the duty of obedience to the authority that comes from God. But it is also from the principles of religion that the judges' duty arises to justly judge without distinguishing people according to their background and of-

\footnotetext{
${ }^{13}$ Ibid, 22-23.

${ }^{14}$ Ibid, 24-25.
} 
fice they hold, because God will take vengeance on unjust judges and officials for the wrongs that they caused, as they were appointed to serve the nation. It is from religion that the fact issues that honesty, being just, and the ancillary nature of authority are a duty and do not depend on the choice and will of those wielding power, as contemporary philosophers said. The duties are also emphasized by the threat of earthly, as well as eternal, punishments, which cannot happen in a case when only the official's own will is the deciding factor.

Being aware of the threat of these punishments is, according to the preacher, indispensable, because people have a natural inclination to give in to the passions and weaknesses of their character, and to satisfy their love of themselves more than to carrying out their citizen's duties. ${ }^{15}$ This is why, when performing public duties, one has to realize the inevitability of the punishment and of the prize in the eternal dimension. Only by having this choice is man more inclined to devote his own earthly comfort to the common good of the nation and to earn the eternal reward in his individual dimension ${ }^{16}$. The preacher assumed an attitude towards this philosophical formulation that was in fashion then, saying that it is not necessary to support the official's and citizen's virtues with the hope of salvation, as the pursuit of glory in the earthly dimension - honors and compatriots' plaudits - is sufficient. Lipiński did not deny that the pursuit of fame contributed to the creation of many useful works. However, it was also the source of hypocrisy when misdeeds are presented as works of virtue. In this formulation, there is a clear polemic with the Machiavellian conviction about the end that justifies the means ${ }^{17}$. The preacher stressed that, for his personal fame, a man is able to reach the top of his intellectual abilities or of his courage. But if his own fame is the only motive for his action, he will not commit himself to everyday problems that cannot put him on a pedestal and will not assure plaudits. How could he face up to everyday painstaking work that does not meet with constant applause? On the other hand, an official who is a profound believer knows that God sees and will assess all his deeds - both those that are examples of exceptional heroism and the seemingly imperceptible everyday work.

In the next fragment of his argument Rev. Lipiński presented a number of examples from the Bible proving that man's evil deeds resulting from vain-

\footnotetext{
${ }^{15}$ Ibid., 31-32.

${ }^{16}$ Ibid., 33-34.

${ }^{17}$ Ibid., 35.
} 
glory and love for himself were punished by God. ${ }^{18}$ They all proved that God is sensible to social good and soon punishes those who destroy it for their own profit, and particularly when they are entrusted with authority. It is true, the preacher remarked, that the philosophers with whom he argued also mentioned punishment for evil deeds. But they saw it only in the form of pangs of conscience bothering unjust officials. However, he immediately added that only from the perspective of eternal damnation do pangs of conscience gain a proper significance. In other cases, one may not become upset, for the judgment of other citizens may be molded, their vigilance relaxed, and a misdeed may be hidden from the eyes of the judges and the ruler. The official may then be sure that he will not be punished, and if he does not believe in eternal punishment his conscience will also not disturb him. A lot of officials are so demoralized that they present misdeeds as conforming with the binding law. In such a situation only a conscience formed on the religious foundation is able to stop them from such behavior. ${ }^{19}$

For the preacher, and probably the listeners, the basic conclusion following from this argument was that the Christian religion is the fundamental principle on which the civil society and the state of law are built. Without religion, authority is not able to secure peace inside the country. Only from the principles of religion do both laws and civil duties issue, as well as the ethos of officials of any level. This is why the bond between the Church and the state is especially necessary for the latter. On the other hand, God burdened monarchs with the duty of taking special care of the religion in the countries they rule. ${ }^{20}$ Hence, the alliance of the throne and the altar is the result of the work of Divine Providence. In such a situation the preacher addressed the monarch, calling for him to regain the Old Polish sacred character of religion in the Duchy of Warsaw, for it is only on this foundation that the restoration of the Republic of Poland would be possible. And this is the task Divine Providence entrusted Frederick Augustus with. The restoration of the piety of the old times will revive the nation again -civil zealousness will return. The sermon is concluded with an invocation calling God to revive Poland. ${ }^{21}$

\footnotetext{
${ }^{18}$ Ibid., 38-40. The author cited the history of Cain, complaints against God and Moses during the exodus from Egypt, the history of Haman, Absalom, Ahab and Jezebel.

${ }^{19}$ Ibid., 43-45.

${ }^{20}$ Ibid., 46.

${ }^{21}$ Ibid., 50-51. It is worth remembering that Frederick Augustus was personally a very religious man; in his decisions he tried to accommodate the Church as much as he could, so the preacher hoped that he would take the admonitions and requests to heart, especially because they concerned officials nominated by the king.
} 
In fact, Rev. Augustyn Lipiński's sermon does not present a new philosophical system. It only reminds us of the Church's former teachings on authority, of the fact that it comes from God, of the hierarchical arrangement of the society that follows it, and of its members' rights and duties. However, what was most interesting for the preacher here was the ethos of the state official. An official wields power, but his power is not given by Divine Providence. He is appointed by the king and is supposed to carry out defined tasks in the post indicated. Thus, both from the duties to the king and the nation, that is co-citizens, it follows that an official, irrespective of the level of his office in the hierarchy, has to serve the monarch and the nation. Hence performing an official's duties is a service to others. And it may not have anything in common with aspiring to be promoted or, what is worse, to gain profit for the official himself. A virtuous official should be a model of civic virtues when serving at his post. And a good citizen should be ready to sacrifice himself and all he has for the good of the country and the nation. ${ }^{22}$

However, the context of the event should be realized. The Krakow Canon, Augustyn Lipiński, delivered the argument in the presence of Frederick Augustus, the persons accompanying him, both his family and the court, and the Minister of War of the Duchy of Warsaw, the Prefect of the Krakow Department, departmental and municipal officials. And he most clearly directed his words to the officials. It could be said that the arguments concerned a situation that was generally known. On the one hand, there was the rather universal conviction of his contemporaries about a fall in religiousness, especially among the higher classes, educated, aspiring to be modern. ${ }^{23}$ On the

\footnotetext{
${ }^{22}$ It is worth saying that the argument was not written by Lipiński for the needs of this particular address. He presented the audience with his views on the issues connected with wielding power. If the discussed sermon contains a theoretical discourse, a couple of months before, in a sermon delivered in the Krakow Cathedral during the obsequies for Stanisław Małachowski, he had presented the former Marshal of the Great Sejm not as a model remaining in the sphere of ideas, but as a real one of a perfect citizen and a virtuous official who exclusively aimed for the good of the country. Leaving aside the fact that in a funeral sermon the late person should be presented panegyrically, Lipiński expressed his convictions with respect to the subject discussed, presenting the late Marshal as an example, cf. Kazanie na uroczystych exekwiach za nieśmiertelnej pamięci Stanisława Małachowskiego prezesa senatu i pierwszego wojewodę Xięstwa Warszawskiego $w$ kościele katedralnym krakowskim miane przez x. Augustyna Lipińskiego kustosza katedralnego krakowskiego dnia 26 stycznia 1810 [The Sermon Delivered by Rev. Augustyn Lipiński, the Krakow Cathedral Custodian In the Krakow Cathedral Church at the Solemn Obsequies for Stanisław Małachowski, Chairman of the Senate and the First Voivode of the Duchy of Warsaw on 26 January 1810].

${ }^{23}$ Undoubtedly, some influence on the degeneration of the old forms of religiousness in the higher classes of the society, or on passing towards utilitarian and the customary treatment of religious practices was exerted by the Enlightenment philosophy as early as the $18^{\text {th }}$ century and by
} 
other hand it was impossible not to notice the actually feeble condition of the class of officials in the Duchy, especially as far as their competences were concerned. ${ }^{24}$ In such a situation the preacher considered it his duty to remind them who an official in a state really is - he is a servant of the nation and of the state. And it is their good that should be his greatest care. This is because the essence of the authority is its ancillary character with respect to the king (and, indirectly, to God) as well as to the nation and the state.

The words of this sermon could seem harsh since, in an unambiguous way that left no doubts, they reviled a certain philosophy of authority. But the duty for Rev. Lipiński to remind those in authority about how they should rule resulted from his profound patriotism ${ }^{25}$. As he remarked, the Church founded by Jesus Christ was eternal, but its task was, among other things, to introduce order into interpersonal relationships so that it could lead the whole community to salvation. Thus, duty also followed from this principle to ad-

eliminating the baroque forms of religiousness. This was why situations were not rare in which religious practices were treated as social conventions, and not as a realization of spiritual needs; see: Pamiętniki hr. Stanisława Wodzickiego [Count Stanisław Wodzicki's Memoirs] (Kraków, 1888), 72-74; Pamiętniki Franciszka z Błociszewa Gajewskiego, pułkownika wojsk polskich (1802-1831) [The Memoirs of Franciszek Gajewski of Błociszew, a Colonel of the Polish Army (1802-1831)] ed. Stanisław Karwowski, vol. I (Poznań, [s.d.]), 71; Karol Górski, "Życie wewnętrzne i religijność mas [The Inner Life and Religiousness of the Masses]," in Historia Kościoła w Polsce [History of the Church in Poland], ed. Bolesław Kumor and Zdzisław Obertyński, vol. II, part. 1 (Poznań, Warszawa: Pallottinum, 1979), 335-337; Stanisław LiTAK, Od reformacji do oświecenia. Kościót katolicki w Polsce nowożytnej [From Reformation to the Enlightenment. The Catholic Church in Modern Poland] (Lublin: Towarzystwo naukowe KUL, 1994), 117-126; Roland Press OFMCap, Powolanie blogostawionych: Honorata i M. Angeli [The Vocation of the Blessed Ones: Honorat and M. Angelo], in Powolanie honorackie [Honoratian Vocations], ed. Agnieszka Kruszyńska (Zakroczym: Wydawnictwo Diecezjalne i Drukarnia w Sandomierzu, 2006), 52-53.

${ }^{24}$ Complaints about the work of officials were common; the state was accused of the excessive bureaucratization of life, the lack of the officials' proper competence, their discretionary decisions, or even ill will and corruption. Certainly, the officials' evident shortcomings were the effect of the fact that, after establishing the Duchy of Warsaw, there were only a few Polish officials because the partitioner governments manned offices with their own officials who, to a large degree, stopped performing their functions after 1807 and 1809; see: Władysław RosTOCKI, Korpus w gęsie pióra uzbrojony. Urzędnicy warszawscy, ich życie i praca w Księstwie Warszawskim i Królestwie Polskim do roku 1831 [The Corps Armed With Goose Feathers. Warsaw Clerks, Their Life and Work in the Duchy of Warsaw and the Kingdom of Poland to 1831] (Warszawa: Państwowy Instytut Wydawniczy, 1972), 20-24, 33-44; IDEM, Rodowód i pozycja społeczna urzędników administracji państwowej i miejskiej w Warszawie (1807-1830) [The Background and Social Standing of the Clerks in the State and Municipal Administration in Warsaw [18071830] in Warszawa XIX wieku (Warsaw in the $19^{\text {th }}$ Century), ed. Ryszard Kołodziejczyk, Juliusz Kosin, and Janina Leskiewiczowa, vol. 3 (Warszawa: 1974), 117-126.

${ }^{25}$ Cf. Baran, Kraków kościelny, 103. 
monish those in authority, to sensitize them to the fact that countries fall because of their officials not being virtuous and their citizens being corrupt, as well as to guard the foundation of the state: the alliance of the throne and the altar, both coming from the will of Divine Providence and complementary to each other. As the Church was supposed to take care of the eternal life of the faithful, so monarchs of the earthly one. This care should be expressed in securing the rights of religion in the country and in keeping watch so that officials at all levels respected this principle.

It seems that only in this aspect is the sermon connected with the feast of St Stanislaus. It became a pretext for explaining the principles on the basis of which authority should function in a country, which St Stanislaus also tried to put into effect when he admonished Bolesław II the Generous for contravening the tenets of religion. This is why Lipiński appealed to the saint to intercede for Frederick Augustus with God, and intercede for his kingdom - Poland. In this meaning, Frederick Augustus was presented as the opposite of Bolesław and so the preacher expressed his conviction that Poland would be reborn under his enlightened and pious rule. ${ }^{26}$

In the aspect of this comparison the preacher was right - the monarch, as was said above, appreciated his care and involvement in the good of the country, granting him the St Stanislaus Order and planning to appoint him the Bishop of Poznań. The officials who listened to the sermon also understood the reproof. The evidence of this is rather perverse. If the press described the monarch's stay in Krakow in detail and the speeches that had been delivered, or at least their summaries were quoted, the fact that Rev. Lipiński preached the sermon was only mentioned in one sentence in Gazeta Krakowska. ${ }^{27}$ Most clearly, not everybody liked the preacher's presentation in such a logical form of the fall of the official's ethos and of the civil attitudes in the nation.

\section{BIBLIOGRAPHY}

BARAN, Zbigniew. "Kraków kościelny w czasach Księstwa Warszawskiego [The Ecclesiastical Krakow in the Times of the Duchy of Warsaw]." In Kraków w czasach Księstwa Warszawskiego [Krakow in the Times of the Duchy of Warsaw], 99-105. Kraków: Towarzystwo Miłośników Historii i Zabytków Krakowa, 1989.

\footnotetext{
${ }^{26}$ Kazanie w dzien' S. Stanistawa (The Sermon Preached on the Day of St Stanislaus), 50-52.

27 "During the service Rev. Canon Lipiński preached an appropriate sermon, and after the end of the service the Royal Couple returned to their palace." GK 1810, No. 39; KLESzCZOwA, Ceremonie i parady, 57.
} 
BARTel, Wojciech. "Lipiński Augustyn Karol Boromeusz." In Polski Słownik Biograficzny [Polish Biographical Dictionary], vol. XVII, 387-388. Wrocław, Warszawa, Kraków: Ossolineum, 1972.

Historia Kościoła w Polsce [History of the Church in Poland], edited by Bolesław Kumor and Zdzisław Obertyński, vol. II, part. 1. Poznań, Warszawa: Pallottinum, 1979.

Kazanie $w$ dzień S. Stanisława biskupa i męczennika, w przytomności najjaśniejszego Fryderyka Augusta króla saskiego, xiqżęcia warszawskiego miane przez x. Augustyna Lipińskiego kustosza katedralnego krakowskiego dnia 8 maja 1810 [The Sermon Delivered by Rev. Augustyn Lipiński, the Krakow Cathedral Custodian in the Presence of His Majesty Frederick Augustus King of Saxony, Duke of Warsaw, on 8 May 1810].

KLESzCzowA, Izabela. Ceremonie i parady w porozbiorowym Krakowie 1796-1815 [Ceremonies and Parades in Post-Partition Krakow 1796-1815]. Kraków: Wydawnictwo Uniwersytetu Jagiellońskiego, 1999.

ŁĘTOWSKI, Ludwik. Katalog biskupów, prałatów i kanoników krakowskich [A Catalogue of Krakow Bishops, Prelates and Canons], vol. III. Kraków: W drukarni Uniwersytetu Jagiellońskiego, 1852.

RostockI, Władysław. Korpus w gęsie pióra uzbrojony. Urzędnicy warszawscy, ich życie i praca w Księstwie Warszawskim i Królestwie Polskim do roku 1831 [The Corps Armed With Goose Feathers. Warsaw Clerks, Their Life and Work in the Duchy of Warsaw and the Kingdom of Poland to 1831]. Warszawa: Państwowy Instytut Wydawniczy, 1972.

\section{ON A VIRTUOUS OFFICIAL AND A GOOD CITIZEN: CANON AUGUSTYN LIPIŃSKI'S PHILOSOPHY OF EXERCISING POWER (BASED ON THE SERMON PREACHED IN KRAKOW ON $8^{\text {th }}$ MAY 1810)}

$\mathrm{Sum}$ mary

This article is devoted to a presentation of the contents of one of the political sermons preached in Krakow Cathedral on 8th May 1810. A Cathedral Canon, Rev. Augustyn Lipiński delivered it on the feast of St Stanislaus in the presence of King Frederick Augustus I of Saxony and Duke of Warsaw, his court and the dignitaries who accompanied him: the Minister of War, Prince Józef Poniatowski, the Prefect of the Krakow Department, Prince Henryk Lubomirski, and many department and municipal officials. In its content the sermon was devoted to authority and the way to exercise it. It is constructed as a polemic with contemporary currents striving after secularization of the ethos of the official. The preacher expressed his conviction that a virtuous official and a good citizen are ones who regard the good of the country and of their fellowcitizens more highly than their own good or even their lives; they are ready to serve them and the king who is exercising power by the will of Providence, and they never look to their own gain in this service - either material profits or fame.

Key words: Duchy of Warsaw; the Church in the Duchy of Warsaw; Polish sermons.

Translated from Polish by Tadeusz Karlowicz

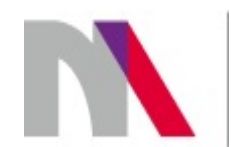

The preparation of the English version of Roczniki Humanistyczne and its publication in electronic databases was financed under contract no. 836/P-DUN/2018 from the resources of the Minister of Science and Higher Education for the popularization of science. 